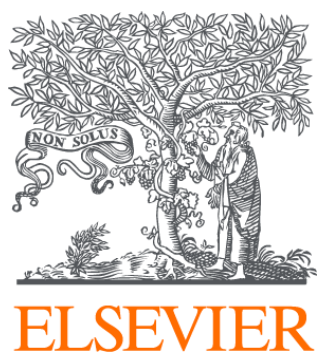

Since January 2020 Elsevier has created a COVID-19 resource centre with free information in English and Mandarin on the novel coronavirus COVID-

19. The COVID-19 resource centre is hosted on Elsevier Connect, the company's public news and information website.

Elsevier hereby grants permission to make all its COVID-19-related research that is available on the COVID-19 resource centre - including this research content - immediately available in PubMed Central and other publicly funded repositories, such as the WHO COVID database with rights for unrestricted research re-use and analyses in any form or by any means with acknowledgement of the original source. These permissions are granted for free by Elsevier for as long as the COVID-19 resource centre remains active. 


\title{
Increased mood disorder symptoms, perceived stress, and alcohol use among college students during the COVID-19 pandemic
}

\author{
Nora E. Charles $^{a, *}$, Stephanie J. Strong ${ }^{\text {a, Lauren C. Burns }}{ }^{\text {a }}$, Margaret R. Bullerjahn ${ }^{\text {a }}$, \\ Katherine M. Serafine ${ }^{b}$ \\ ${ }^{a}$ School of Psychology, The University of Southern Mississippi, Hattiesburg, MS USA \\ ${ }^{\mathrm{b}}$ Department of Psychology, The University of Texas at El Paso, El Paso, TX USA
}

\section{A R T I C L E I N F O}

\section{Keywords:}

COVID-19

Coronavirus

Depression

Stress

Alcohol

Young adults

\begin{abstract}
A B S T R A C T
The COVID-19 pandemic caused significant disruption during the spring of 2020. Many college students were told to leave campus at spring break and to complete the semester remotely. This study evaluates effects of this disruption on student well-being. Measures of psychological symptoms, perceived stress, and alcohol use during the pandemic were completed by 148 students in spring 2020 and 352 students in fall 2020 at a university in the southeastern U.S. Results from both cohorts were compared to 240 students who completed the same measures in the fall 2019 semester. Participants in spring 2020 reported more mood disorder symptoms, perceived stress, and alcohol use than did pre-pandemic participants and worry about COVID-19 was negatively associated with wellbeing. By fall 2020 symptoms had largely returned to pre-pandemic levels. In general, White students reported a greater effect of the pandemic on well-being than did African American students. Young adults appear to be less vulnerable to the most serious medical complications associated with COVID-19, but nonetheless experience psychological effects from the pandemic. Universities and practitioners who work with college students can help young adults manage their symptoms and avoid behaviors like risky alcohol use when confronted with stressors such as the COVID-19 pandemic.
\end{abstract}

\section{Introduction}

The SARS-CoV-2 virus that causes COVID-19 was first detected in China in late 2019 and quickly spread across the globe, causing significant concern for public health as well as disruption to daily life as governments began to restrict citizens' movements and mandate behavioral changes in an effort to reduce the transmission of the virus. On March 17, 2020, the COVID-19 outbreak was declared a national emergency in the United States as the number of cases grew to over 4,000 with a death toll of about 75 (Centers for Disease Control and Prevention, 2020a). This was rapidly followed by an increase in the prevalence of COVID-19 throughout the country, associated strain on medical systems, and a significant increase in deaths attributed to COVID-19. Federal, state, and local leaders responded with orders to close schools and businesses and limit or cancel public gatherings. In the United States, the number of cases and deaths associated with COVID-19 continued to rise for the remainder of 2020, at higher rates than were found in many other countries, and disruption in the form of school closures, restrictions on gatherings, and other measures intended to reduce the spread of the virus persisted. The impact of COVID-19 on physical health was the primary focus during this turbulent time; however, it is also important to consider how experiencing the pandemic affects mental health and well-being. Although young adults appear to be less vulnerable to the worst health complications associated with COVID-19 (Wu and McGoogan, 2020), they are nonetheless impacted as the pandemic may interfere with their academic, occupational, and interpersonal functioning. Accordingly, this study aimed to better understand the psychological well-being of two samples of college students, one surveyed during the initial weeks of mass closures and physical distancing orders in the United States and one surveyed once the effects of the pandemic on daily life were more entrenched in late 2020 , and to compare their data with results collected from a similar sample prior to the emergence of COVID-19.

Research on the psychological impact of previous disease outbreaks offers some insight into what might be expected as a result of the COVID19 pandemic, though most of this research is focused on individuals who

\footnotetext{
* Corresponding author.

E-mail address: nora.charles@usm.edu (N.E. Charles).
} 
were confirmed to be exposed to the diseases or diagnosed with them rather than those in the general public. Individuals exposed to or infected with MERS (Batawi et al., 2019; Lee et al., 2018), Ebola (Mohammed et al., 2015), and SARS (Mak et al., 2009) reported psychological effects such as traumatic stress symptoms, difficulty concentrating, worry that interfered with sleep, depression, and a lower quality of life. Even if one does not contract these diseases, being quarantined as a result of exposure appears to have a negative effect on well-being. A review of research on the effects of quarantine reported increases in post-traumatic stress symptoms and anger. It also determined that a longer length of quarantine, limited available information about the crisis, financial loss as a result of the outbreak or quarantine, and stigma in society associated with potential exposure to the disease can all exacerbate these effects (Brooks et al., 2020). Research on the effects of shelter at home orders and similar directives in response to the COVID-19 outbreak is limited, but there is evidence that individuals who are able to keep working experience less negative impact on their mental health than do those who become unemployed (Zhang et al., 2020).

For members of the general public, a pandemic and the associated societal disruption are stressful even when one is not infected or at particularly high risk of exposure to the infection. Community members in Singapore during the SARS outbreak reported elevated rates of posttraumatic stress symptoms, depression, and anxiety (Sim et al., 2010). A study on the mental health impact of SARS among women in Hong Kong found elevated rates of depression and perceived stress (Yu et al., 2005). Similarly, a significant proportion of community respondents in the United Kingdom during the swine flu outbreak reported being "fairly" or "very" worried about the disease (Rubin et al., 2010). During the Ebola outbreak in Africa, fear of contracting the disease led to distrust among community members and frayed social relationships (Van Bortel et al., 2016). These findings are important for our understanding of the overall impact of disease outbreaks, as psychological effects occurring in a substantial proportion of the community impact not only the daily functioning of those individuals but also the resilience of the community as a whole (Allenby and Fink, 2005).

Comparatively less is known about the psychological impact of COVID-19, but several early studies have sought to document mental health symptoms during the pandemic. One study of a general sample of adults in China found that over half of respondents described the psychological impact of COVID-19 as moderate or severe (C. Wang et al., 2020b). Across several studies, specific effects on mental health among adults in the general public in China have included depression, anxiety, sleep difficulties, and stress (Gao et al., 2020; Huang and Zhao, 2020; Liu et al., 2020; . Wang et al., 2020b; Zhang et al., 2020). Outside of China, a study in Denmark compared pre-pandemic and pandemic data and found a negative impact of COVID-19 on well-being (Sønderskov et al., 2020). Some information about individual differences in the psychological impact of the pandemic have also been reported. Factors such as being female, being a student, being younger than 35 , and being relatively more concerned about loved ones contracting the disease were associated with greater impact whereas having a low perceived risk of infection was associated with less impact (Huang and Zhao, 2020; Liu et al., 2020; C. Wang et al., 2020b). These studies provide valuable information about the mental health effects of the pandemic but also have some limitations, including the scope of mental health symptoms assessed and, for most, the lack of a pre-pandemic comparison group. Several studies have examined the impact of the COVID-19 pandemic specifically on college students. Studies based in China have found that many college students are able to cope effectively with the pandemic but that a significant minority report clinically significant symptoms of anxiety, post-traumatic stress, and depression (Cao et al., 2020; Chi et al., 2020). One study in France found that college students surveyed during a mandatory confinement period in spring 2020 reported that their anxiety and stress levels had increased during the quarantine period, and this was especially true among students who remained in their school year residence and did not relocate to stay with family during the pandemic (Husky et al., 2020). In the United States, researchers have found similar results that include increases in anxiety, depression, somatization, suicidality, and stress during the pandemic among college students surveyed in spring 2020 (Kecojevic et al., 2020; X. Wang et al., 2020). Unfortunately, none of these studies include a comparison group so it is not possible to compare whether symptoms during the pandemic exceed the typical prevalence among college students in any of these cultures. Only one study to date has reported on changes in symptoms during the pandemic using a longitudinal design. Copeland and colleagues (2020) found that inattention and externalizing scores were higher on a survey at the end of the spring 2020 semester than at the beginning, and that daily diaries revealed that mood and engagement in healthy behaviors decreased while stress increased once the pandemic began to affect life at the university.

Beyond the effects on mental health, the pandemic may also impact young adults' substance use patterns. Chronic stress, which is likely to occur with prolonged disruption related to the COVID-19 pandemic, can lead to the development of anxiety disorders (Baum and Posluszny, 1999). Individuals with anxiety disorders, including post-traumatic stress disorder (PTSD), are at increased risk for heavy alcohol use (Overstreet et al., 2017) and developing alcohol use disorder (AUD; Kessler et al., 1995; Paltell et al., 2020). Importantly, high levels of stress, even in the absence of the development of an anxiety disorder, are also associated with increased alcohol use and the development of AUD (Keyes et al., 2012). AUD is also the most common comorbidity diagnosed among individuals with depressive disorders (McHugh \& Weiss, 2019). These results suggest that the increases in anxiety, depression, and stress that have been observed in response to COVID-19 may be associated with increased alcohol use, though this has not been assessed directly. Because the onset of AUD typically occurs in young adulthood (Grant et al., 2015) and college enrollment has been associated with an increased risk of AUD (Slutske, 2005; Slutske et al., 2004) college-aged individuals may be particularly at high risk of developing problematic alcohol use patterns during the COVID-19 pandemic. These increases in alcohol use and related problems may be seen in the immediate aftermath of the pandemic arriving in the United States and leading to changes in daily life and restrictions on activities, and they may also be seen later on as the pandemic produces more sustained negative impacts related to social isolation, financial hardship, and other sources of chronic stress.

Many college students experienced greater disruption to their living situation, work, and education during the COVID-19 pandemic than did other groups in society. Additionally, they may be concerned about the impact of the pandemic on their academic progress and ability to enter the workforce. College students who were not living with their parents prior to the pandemic may also be troubled by returning to a living environment that may not be as comfortable as their college environment or as conducive to their now-online learning; further, they may worry about transmitting the virus from their college to their family's household. Given that approximately $20 \%$ of college students have a mental health disorder, though many go untreated (Auerbach et al., 2016), and roughly the same proportion have clinically significant problems with alcohol misuse (Slutske, 2005) this population may be at particular risk for problems in these domains during the pandemic. Consequently, the current study was designed to assess the presence of symptoms of psychological disorders, alcohol misuse, and perceived stress in one sample of college students during the initial weeks of shutdowns and disruptions to community life during the COVID-19 pandemic in the United States and in a second sample roughly six months later, once more sustained effects of the pandemic had become a part of daily life. Data collected during the pandemic is compared to data collected in the fall 2019 semester in order to assess the extent to which symptoms appear to be related specifically to the pandemic situation. Based on the data available about associations between stressful events and both mental health and substance use disorders, it was hypothesized that participants surveyed during the pandemic would report higher 
levels of depression and anxiety symptoms, perceived stress, and alcohol misuse. Additionally, it was expected that reported concern about COVID-19 would relate to symptom levels. Further, exploratory analyses of racial differences in the impact of the COVID-19 pandemic and the sustained impact of the COVID-19 pandemic on well-being after several months are examined.

\section{Methods}

\subsection{Participants}

Data on perceived stress, coping, and psychological symptoms were collected from 254 college students at a medium-sized public research university in the southeastern United States during September through November of the fall 2019 semester. Data on these symptoms were also collected from 168 participants from the same university beginning on April 1, 2020, during the first week when the university's campus was closed due to COVID-19 and classes had been moved online for the duration of the term, and continuing until the end of the spring semester in early May. A third round of data were collected from 352 students at the same university in October and November of 2020. In total, the majority of the sample was female (84\%) and White (61.2\%). The mean age of participants was 21.16 years old.

\subsection{Procedure}

This study was approved by the Institutional Review Board at the university where data collection took place and all participants provided informed consent prior to responding. The fall 2019 data collection had been approved as part of a larger study on health risk behaviors. When the COVID-19 outbreak spread to the US during the spring 2020 semester, an IRB amendment adding questions about COVID-19 to the questionnaire battery was approved and data collection was reopened to new participants for the spring 2020 and fall 2020 semesters. Participants in all samples were members of the university's psychology subject pool who completed questionnaires online using Qualtrics survey software and received credit that could be used for course requirements or extra credit. Measures were counterbalanced across four versions of the survey that were randomly assigned to reduce the likelihood of order effects. Additionally, two quality assurance questions were embedded within the survey (e.g. "Please select 'Disagree Strongly' to answer this item"). Participants who did not meet the quality assurance requirements were removed from the participant pool.

\subsection{The COVID-19 context of the study}

During data collection for the spring 2020 sample, the COVID-19 outbreak spread across the U.S. and numbers of cases and associated deaths continued to increase while measures such as shelter in place orders were being rolled out by state and local governments. On April 1, more than 213,000 people were diagnosed with COVID-19 in the U.S. By May 8 , that number had increased to $1,248,040$, and by the end of November 2020 the number of cases in the U.S. was 12,598,660 (CDC, 2020a). By the week before data collection began in spring 2020, ending on March 28, there had been over 2,000 deaths attributed to COVID-19 across the country (CDC, 2020b). Data collection for that semester ended the week of May 8, at which point over 75,000 deaths in the U.S. had been attributed to COVID-19 (CDC, 2020c). For the fall 2020 sample, data collection began on October 9 when 210,338 deaths were reported as a result of COVID-19 in the U.S. (WHO, 2020).

Notably, the COVID-19 pandemic is somewhat unique relative to other disease outbreaks because of the extreme physical distancing and quarantine measures taken by officials in many jurisdictions. On April 1, 32 states were under stay-at-home orders. Ten states and the District of Columbia, including the state where data collection was based, enacted similar orders during the first week of April. Toward the end of the data collection period, some states began to relax their restrictions. The state in which data collection was based continued to have a "safer at home" order but also gradually eased restrictions towards the end of the spring 2020 data collection period (Mervosh et al., 2020) and never returned to the most restrictive state-wide guidelines.

Several universities, including the university at which this study was conducted, closed their campuses and moved spring 2020 classes online to comply with social distancing guidelines. Although the move to online classes and this study's online data collection meant that participants might be completing this study from anywhere in the U.S., the university where data were collected typically enrolls most of its undergraduates from the state where the university is located and a handful of neighboring states in the southeastern U.S. An examination of data collection locations from Qualtrics confirmed that $60.1 \%$ of participants were responding from the state where the university is located and $32.1 \%$ were located in neighboring states in the southeastern U.S. Notably, $8.1 \%$ were responding from the New Orleans metropolitan area, which had a higher number of cases and COVID-19-associated deaths than did the surrounding areas during this period of data collection.

In fall 2020, most universities, including the one where data collection took place, were primarily teaching online courses. However, students were allowed to move on campus if they desired and to use some campus facilities as long as physical distancing was possible and students wore masks/PPE. In this semester, $83 \%$ of participants responded to the survey from within the state.

\subsection{Measures}

\subsubsection{Questions about COVID-19}

Participants' knowledge and perceptions of COVID-19 were measured through a questionnaire created by the research team (see Table 1 for the full list of questions). The measure consisted of Likert scale questions regarding worry surrounding the personal and community impact of COVID-19, changes in daily behavior, and thoughts on how people, including government officials and the media, have responded to the pandemic. Participants were also asked about the level of personal and community exposure they have had to COVID-19.

\subsubsection{DSM 5 Self-Rated Level 1 Cross-Cutting Symptoms Measure- Adult (CCSM)}

The CCSM (APA, 2014) is a 23-question self-report measure of symptoms across 13 psychiatric domains. Participants report on symptoms experienced in the past two weeks using a 5-point Likert scale $(0=$ none or not at all to $4=$ severe or nearly every day). Domains include depression, anger, mania, anxiety, somatic symptoms, suicidal ideation, psychosis, sleep problems, memory, repetitive thoughts and behaviors, disassociation, personality functioning, and substance use. Domains are scored based on the highest symptom level indicated for any symptom in that domain. This measure has demonstrated good test-retest reliability (Narrow et al., 2013) and clinical utility (Mościcki et al., 2013).

\subsubsection{Perceived Stress Scale}

The Perceived Stress Scale (Cohen, Kamarck, \& Mermelstein, 1983) is a 10-item self-report measure that assesses the appraisal of stress participants have experienced in their lives within the past month. Questions are measured on a 5-point Likert scale $(0=$ Never to $4=$ Very Often) and are designed to assess how uncontrollable, unpredictable, and overloaded individuals perceive their lives as well as their current state of stress. This measure has shown good psychometric properties (Lee, 2012).

\subsubsection{Alcohol Use Disorders Identification Test (AUDIT)}

The AUDIT (Babor et al., 2001) is a 10-item self-report measure to assess the presence of alcohol use and alcohol related problems. Items are rated using a 5 -point Likert scale $(0=$ never to $4=$ daily or almost 
Table 1

COVID-19 Questions

\begin{tabular}{|c|c|}
\hline $\begin{array}{l}\text { 1. How informed do you feel about the } \\
\text { COVID-19 (also known as coronavirus) } \\
\text { outbreak? }\end{array}$ & $\begin{array}{l}1=\text { Not very informed } 234= \\
\text { Somewhat informed } 567=\text { Very } \\
\text { informed }\end{array}$ \\
\hline $\begin{array}{l}\text { 2. How worried are you about the effects } \\
\text { of COVID-19 for you personally? }\end{array}$ & $\begin{array}{l}1=\text { Not very worried } 234=\text { Somewhat } \\
\text { worried } 567=\text { Very worried }\end{array}$ \\
\hline $\begin{array}{l}\text { 3. How worried are you about the effects } \\
\text { of COVID-19 for your loved ones (e.g., } \\
\text { family, friends, romantic partner)? }\end{array}$ & $\begin{array}{l}1=\text { Not very worried } 234=\text { Somewhat } \\
\text { worried } 567=\text { Very worried }\end{array}$ \\
\hline $\begin{array}{l}\text { 4. How worried are you about the effects } \\
\text { of COVID- } 19 \text { for the community in } \\
\text { general? }\end{array}$ & $\begin{array}{l}1=\text { Not very worried } 234=\text { Somewhat } \\
\text { worried } 567=\text { Very worried }\end{array}$ \\
\hline $\begin{array}{l}\text { 5. How do you think COVID-19 compares } \\
\text { to the seasonal flu? }\end{array}$ & $\begin{array}{l}1=\text { It's much less of a problem } 234= \\
\text { They are equally problematic } 567=\text { It } \\
\text { is much more of a problem }\end{array}$ \\
\hline $\begin{array}{l}\text { 6. How necessary is it for you to change } \\
\text { your daily behavior to reduce the } \\
\text { spread of COVID-19? }\end{array}$ & $\begin{array}{l}1=\text { Not at all necessary } 234= \\
\text { Somewhat necessary } 567=\text { Extremely } \\
\text { necessary }\end{array}$ \\
\hline $\begin{array}{l}\text { 7. How necessary is it for changes to } \\
\text { occur in the community (e.g., } \\
\text { workplaces closing, public events } \\
\text { cancelled) in order to reduce the spread } \\
\text { of COVID-19? }\end{array}$ & $\begin{array}{l}1=\text { Not at all necessary } 234= \\
\text { Somewhat necessary } 567=\text { Extremely } \\
\text { necessary }\end{array}$ \\
\hline $\begin{array}{l}\text { 8. How do you think the people you are } \\
\text { close with (family, friends) are reacting } \\
\text { to the COVID-19 outbreak? }\end{array}$ & $\begin{array}{l}1=\text { They are not being careful enough } 2 \\
34=\text { They are being the right amount } \\
\text { of careful } 567=\text { They are overreacting }\end{array}$ \\
\hline $\begin{array}{l}\text { 9. How do you think the government is } \\
\text { reacting to the COVID-19 outbreak? }\end{array}$ & $\begin{array}{l}1=\text { They are not being careful enough } 2 \\
34=\text { They are being the right amount } \\
\text { of careful } 567=\text { They are overreacting }\end{array}$ \\
\hline $\begin{array}{l}\text { 10. How do you think the media is } \\
\text { reacting to the COVID-19 outbreak? }\end{array}$ & $\begin{array}{l}1=\text { They are not being careful enough } 2 \\
34=\text { They are being the right amount } \\
\text { of careful } 567=\text { They are overreacting }\end{array}$ \\
\hline $\begin{array}{l}\text { 11. How many positive cases of COVID-19 } \\
\text { are currently in your state or country? } \\
\text { You can provide an exact number, an } \\
\text { estimate, or say I don't know. }\end{array}$ & \\
\hline $\begin{array}{l}\text { 12. Are there confirmed COVID- } 19 \text { cases } \\
\text { in your city or town? }\end{array}$ & Yes No I'm not sure \\
\hline $\begin{array}{l}\text { 13. Do you personally know anyone who } \\
\text { has tested positive for COVID-19? }\end{array}$ & Yes No \\
\hline $\begin{array}{l}\text { 14. Do you personally know anyone who } \\
\text { is currently sick with the flu or a cold? }\end{array}$ & Yes No \\
\hline $\begin{array}{l}\text { 15. Do you personally know anyone who } \\
\text { is at-risk for especially negative } \\
\text { outcomes if they catch COVID-19 (e.g., } \\
\text { elderly, has a compromised immune } \\
\text { system)? }\end{array}$ & Yes No \\
\hline
\end{tabular}

daily) and gauge the frequency, amount, and consequences of alcohol use participants experience. This measure has demonstrated utility for detecting alcohol misuse in the general population using sex-specific cutoff values (Johnson et al., 2013).

\subsection{Data analysis}

Data were first evaluated to determine whether participants passed QA controls embedded in the materials and whether there was missing data on variables of interest. Following this, differences in demographic features of the sample across the semesters were evaluated. Next, the internally-developed questions about COVID-19 were analyzed and relations between these items and the well-being variables among participants in the spring 2020 and fall 2020 samples were tested using nonparametric correlations. Finally, the effect of completing the study during the pandemic vs. in the semester prior was examined using multivariate or univariate General Linear Models (GLMs), as appropriate, conducted separately for each measure of well-being due to some participants not completing all measures (described in more detail below). All analyses were conducted in SPSS v26.

\section{Results}

\subsection{Description of sample and handling of missing data}

Eighty-nine participants failed quality assurance checks and were excluded from analyses, leaving samples of 240 for the fall 2019 semester, 148 for spring 2020, and 297 for fall 2020. Participants in all semesters were primarily female $(87.9 \%, 86.5 \%$, and $81.5 \%$, respectively) however, they differed in racial makeup (see Table 2). The data were evaluated for missingness and less than $5 \%$ of the overall data were missing. The missing data was evaluated using Little's (1988) test, which was not significant $(\chi 2(313)=315.94, p .=44)$ indicating the data were missing completely at random (MCAR). No data were missing from the demographic information, though eight participants (1.1\%) entered the current date instead of their birthdate when prompted and were excluded from analyses involving age. Some participants had missing data on other measures, typically in the form of an entire measure being skipped. In total, 634 participants (92.6\%) had complete data on all measures. Given the low amount of missing data and the pattern by which it was missing, results for specific measures contain data for only those participants who completed that measure.

\subsection{Associations among indicators of psychological well-being}

A number of the outcomes of interest were correlated with one another, suggesting that many of the symptoms assessed in this study cooccur. The strongest positive associations found between indicators of psychological well-being were dissociation with personality functioning (fall 19: $\mathrm{r}(239)=.64, \mathrm{p}<.01$, spring 20: $\mathrm{r}(147)=.66, \mathrm{p}<.01$; fall 20: $\mathrm{r}$ $(285)=.68, \mathrm{p}<.01)$, suicidal ideation with psychosis (fall 19: $\mathrm{r}(239)=$ $.65, \mathrm{p}<.01$, spring 20: $\mathrm{r}(147)=.41, \mathrm{p}<.01$; fall 20: $\mathrm{r}(285)=.45, \mathrm{p}<$ .01 ), and depression with anger (fall 19: $\mathrm{r}(239)=.58, \mathrm{p}<.01$, spring 20: $\mathrm{r}(147)=.58, \mathrm{p}<.01$; fall 20: $\mathrm{r}(285)=.66, \mathrm{p}<.01)$

Table 2

Demographics

\begin{tabular}{|c|c|c|c|c|}
\hline & Fall 2019 Semester N (\%) & Spring 2020 Semester N (\%) & Fall 2020 Semester N(\%) & Total N (\%) \\
\hline \multicolumn{5}{|l|}{ Sex } \\
\hline Male & $28(11.7)$ & $18(12.2)$ & $66(18.8)$ & $46(11.9)$ \\
\hline Female & $211(87.9)$ & $128(86.5)$ & $283(80.4)$ & $339(87.4)$ \\
\hline Prefer not to say & $1(.4)$ & $2(1.4)$ & $3(.9)$ & $3(.8)$ \\
\hline \multicolumn{5}{|l|}{ Race/Ethnicity } \\
\hline Black or African American & $74(30.8)$ & $70(47.3)$ & $105(29.8)$ & $144(37.1)$ \\
\hline White or Caucasian & $154(64.2)$ & $73(49.3)$ & $226(64.2)$ & $227(58.5)$ \\
\hline Latinx & $13(5.4)$ & $11(7.4)$ & $10(3.4)$ & $34(5.0)$ \\
\hline Asian & $6(2.5)$ & $1(.7)$ & $11(3.1)$ & $7(1.8)$ \\
\hline \multirow[t]{2}{*}{ Other } & $6(2.5)$ & $4(2.7)$ & $6(1.7)$ & $10(2.6)$ \\
\hline & $\mathrm{M}(\mathrm{SD})$ & $\mathrm{M}(\mathrm{SD})$ & $\mathrm{M}(\mathrm{SD})$ & $\mathrm{M}(\mathrm{SD})$ \\
\hline Age & $20.79(5.27)$ & $21.77(3.90)$ & $20.84(5.21)$ & $21.16(4.81)$ \\
\hline
\end{tabular}




\subsection{Questions about COVID-19}

Participants were asked to respond to internally-developed questions about COVID-19. In spring 2020, 138 participants (93.2\%) completed these items. In fall 2020, 296 participants (99.7\%) completed these items. The items had 7-point Likert scales for which a 7 indicates a greater level of the construct being assessed (i.e., more informed, more worried). Items assessing others' reactions to the pandemic were reverse-scored such that low scores on these items indicate that the respondent believes people are not being careful enough about COVID19. Overall, participants reported feeling relatively well-informed about COVID-19, being more concerned about the dangers of COVID-19 for others than for themselves, and believing that measures like the closure of businesses and schools were necessary to reduce the spread of COVID19. They also generally approved of the reactions of the government, people in their lives, and the media to the threat of COVID-19. The vast majority of participants (89.1\% spring $2020,90.1 \%$ fall 2020) reported that there were COVID-19 cases in their city or town at the time of data collection and many reported personally knowing someone who had tested positive for COVID-19. Notably, endorsement of the latter item increased from $12.5 \%$ in week 1 of data collection to $47.8 \%$ in week 6 in the spring 2020 sample. It increased further to $85.4 \%$ in Fall 2020. Students also reported feeling more informed about COVID-19 but also less worried about it and less supportive of pandemic restrictions in fall 2020 as compared to spring 2020. Full results for responses to the COVID-19 questions are presented in Table 3.

The distributions of scores on the COVID-19 questions were generally non-normal so spearman rank order correlations were used to compare responses on these items to scores on the measures of psychological well-being. Results are displayed in Table 4. A cutoff of $+/$ .20 was used to determine correlations that were meaningful, rather than simply statistically significant, due to the number of correlations conducted and the exploratory nature of analyses involving these novel items. Findings indicate being more worried about the effects of COVID19 for themselves or others and believing that close others were not being careful enough about COVID-19 were associated with poorer wellbeing across several measures in spring 2020. Most of the COVID-19 questions were more closely associated with symptoms during spring 2020 than during fall 2020. Exceptions to this were found for the item about whether the government was being careful enough about COVID, which was associated with perceived stress such that lower scores (feeling that the government is not being careful enough) was associated with greater perceived stressed. Additionally, believing that changes in personal behavior and community activities are not necessary to reduce the spread of COVID was associated with greater alcohol use in fall 2020.

\subsection{Comparison of fall \& spring measures of psychological well-being}

General Linear Models (GLMs) were conducted to compare results on measures of psychological symptoms, perceived stress, and alcohol misuse between students tested during the fall 2019, spring 2020, and fall 2020 semesters. A multivariate GLM was conducted on the full sample as all participants completed the DSM 5 CCSM. As it was hypothesized that the COVID-19 pandemic would have a greater impact on some of the psychological symptoms assessed by this measure than others, univariate effects were examined and the results of these analyses are included in Table 5. Overall, results indicate students participating during the beginning of the pandemic reported significantly more symptoms of depression $(\mathrm{F}(2,679)=3.74, \mathrm{p}=.02)$, anger $(\mathrm{F}(2,679)=$ $8.02, \mathrm{p}<.001)$, and mania $(\mathrm{F}(2,679)=8.77, \mathrm{p}<.001)$ than did students in the pre-pandemic semester or in fall 2020. This analysis also showed that personality problems $(\mathrm{F}(2,679)=17.70, \mathrm{p}<.001)$ and repetitive behaviors $(\mathrm{F}(2,679)=9.98, \mathrm{p}<.011)$ were similar in fall 2019 and spring 2020 but increased in fall 2020. Lastly, somatic complaints declined each semester $(\mathrm{F}(2,679)=7.92, \mathrm{p}<.001)$. Univariate GLMs conducted on the PSS (fall $2019 n=225$, spring $2020 n=141$, fall $2020 \mathrm{n}=285$ ) and the AUDIT (fall $2019 \mathrm{n}=223$, spring $2020 \mathrm{n}=138$, fall $2020 \mathrm{n}=297)$ found that students reported more alcohol use $(\mathrm{F}(2$, $648)=2.50, \mathrm{p}=.08)$ and perceived stress $(\mathrm{F}(2,648)=3.44, \mathrm{p}=.03)$ in spring 2020, at the beginning of the pandemic, than they did in fall 2019 or fall 2020.

A second set of GLMs with main effects of semester and race, along with an interaction between race and semester, were conducted on the subset of participants identifying as Non-Hispanic White or African American in each of the three semesters to examine whether the pandemic appeared to have different effects on the well-being of these different racial groups. Descriptive data and results of the GLM analyses are displayed in Table 6. Main effects of semester were similar to those reported for the original model in the whole sample. There were also main effects of race on anger $(\mathrm{F}(1,621)=8.13, \mathrm{p}=.006)$, mania $(\mathrm{F}(1$, $621)=6.39, \mathrm{p}=.020)$, anxiety $(\mathrm{F}(1,621)=8.15, \mathrm{p}=.004)$, psychosis

Table 3

COVID-19 Question Responses

\begin{tabular}{|c|c|c|c|c|c|c|}
\hline & $\begin{array}{l}\% \text { rating a } 6 \text { or } 7 \\
\text { out of } 7\end{array}$ & $\begin{array}{l}\text { Spring } 2020 \\
\text { Semester }\end{array}$ & $\begin{array}{l}\text { Fall } 2020 \\
\text { Semester }\end{array}$ & & & \\
\hline & Spring 2020 & Fall 2020 & M & SD & M & SD \\
\hline & Semester & Semester & & & & \\
\hline How informed do you feel about the COVID-19 (also known as coronavirus) outbreak? & 47.1 & 60.6 & 5.29 & 1.45 & $5.77^{* * *}$ & 1.18 \\
\hline How worried are you about the effects of COVID-19 for you personally? & 31.9 & 22.6 & 4.31 & 1.92 & $3.87^{* * *}$ & 1.94 \\
\hline $\begin{array}{l}\text { How worried are you about the effects of COVID-19 for your loved ones (e.g., family, } \\
\text { friends, romantic partner)? }\end{array}$ & 60.9 & 57.8 & 5.62 & 1.46 & 5.45 & 1.64 \\
\hline How worried are you about the effects of COVID-19 for the community in general? & 59.4 & 44.4 & 5.55 & 1.52 & $4.93^{* * *}$ & 1.70 \\
\hline How do you think COVID-19 compares to the seasonal flu? & 53.6 & 43.8 & 5.57 & 1.31 & $5.22 * *$ & 1.53 \\
\hline $\begin{array}{l}\text { How necessary is it for you to change your daily behavior to reduce the spread of COVID- } \\
19 ?\end{array}$ & 68.8 & 48.6 & 5.83 & 1.45 & $5.04 * *$ & 1.83 \\
\hline $\begin{array}{l}\text { How necessary is it for changes to occur in the community (e.g., workplaces closing, } \\
\text { public events cancelled) in order to reduce the spread of COVID-19? }\end{array}$ & 78.3 & 60.6 & 6.20 & 1.17 & $5.47^{* *}$ & 1.82 \\
\hline $\begin{array}{l}\text { How do you think the people you are close with (family, friends) are reacting to the } \\
\text { COVID-19 outbreak? }\end{array}$ & 8.0 & 7.3 & 4.21 & 1.25 & 4.07 & 1.15 \\
\hline How do you think the government is reacting to the COVID-19 outbreak? & 27.5 & 37.6 & 3.50 & 1.71 & 3.26 & 1.91 \\
\hline How do you think the media is reacting to the COVID-19 outbreak? & 6.5 & 15.9 & 5.18 & 1.73 & 4.82 & 1.97 \\
\hline \multicolumn{7}{|l|}{$\%$ Yes } \\
\hline Are there confirmed COVID-19 cases in your city or town? & 89.1 & 90.1 & & & & \\
\hline Do you personally know anyone who has tested positive for COVID-19? & 41.3 & $85.4 * *$ & & & & \\
\hline Do you personally know anyone who is currently sick with the flu or a cold? & 17.4 & $29.3^{* * *}$ & & & & \\
\hline $\begin{array}{l}\text { Do you personally know anyone who is at-risk for especially negative outcomes in they } \\
\text { catch COVID-19 (e.g., elderly, has a compromised immune system)? }\end{array}$ & 85.5 & 84.4 & & & & \\
\hline
\end{tabular}

Note: *answers were reverse coded; ** indicates a significant difference between semesters 
Table 4

Correlations between independent and dependent variables

\begin{tabular}{|c|c|c|c|c|c|c|c|c|c|c|}
\hline & $\begin{array}{l}\text { How informed } \\
\text { do you feel } \\
\text { about the } \\
\text { COVID-19 } \\
\text { outbreak? }\end{array}$ & $\begin{array}{l}\text { How worried are } \\
\text { you about the } \\
\text { effects of COVID- } \\
19 \text { for you } \\
\text { personally? }\end{array}$ & $\begin{array}{l}\text { How worried } \\
\text { are you about } \\
\text { the effects of } \\
\text { COVID-19 for } \\
\text { your loved } \\
\text { ones? }\end{array}$ & $\begin{array}{l}\text { How worried are } \\
\text { you about the } \\
\text { effects of COVID-19 } \\
\text { for the community } \\
\text { in general? }\end{array}$ & $\begin{array}{l}\text { How do you } \\
\text { think COVID- } \\
19 \text { compares to } \\
\text { the seasonal } \\
\text { flu? }\end{array}$ & $\begin{array}{l}\text { How necessary is it } \\
\text { for you to change } \\
\text { your daily behavior } \\
\text { to reduce the } \\
\text { spread of COVID- } \\
19 \text { ? }\end{array}$ & $\begin{array}{l}\text { How necessary is it for } \\
\text { changes to occur in } \\
\text { the community in } \\
\text { order to reduce the } \\
\text { spread of COVID-19? }\end{array}$ & $\begin{array}{l}\text { How do you think } \\
\text { the people you are } \\
\text { close with are } \\
\text { reaction to the } \\
\text { COVID-19 } \\
\text { outbreak? }\end{array}$ & $\begin{array}{l}\text { How do you think } \\
\text { the government is } \\
\text { reacting to the } \\
\text { COVID-19 } \\
\text { outbreak? }\end{array}$ & $\begin{array}{l}\text { How do you } \\
\text { think the media } \\
\text { is reacting to the } \\
\text { COVID-19 } \\
\text { outbreak? }\end{array}$ \\
\hline Perceived Stress & $-.251-.013$ & .178 .059 & .183. 136 & .211 .082 & .124 .030 & .084 .099 & .079.127 & $-.206-.150$ & $-.020-.204$ & $-.068-.155$ \\
\hline Depression & $-.116-.010$ & .112 .043 & .190 .152 & . $135-028$ & $.150-.004$ & -.017 .063 & .066 .081 & $-.302-107$ & $.004-.161$ & -.103 -148 \\
\hline Anger & $-.062-.049$ & . 190.033 & . 2005 & .243 .025 & $.089-.041$ & .011 .070 & 012.109 & $-.238-.028$ & $-.080-.122$ & -.108 -.092 \\
\hline Mania & -.074 .074 & . 104.040 & .137 .147 & $.065-.001$ & . $105-043$ & .108 .081 & .110 .066 & .053 .085 & -.005 - -079 & $-.060-.061$ \\
\hline Anxiety & -.093 .005 & .261. 137 & .288. 187 & .193 .045 & .226 .036 & .237. 111 & .095.107 & $-.274-.066$ & -160 & -.131 - -.079 \\
\hline $\begin{array}{l}\text { Somatic } \\
\text { Complaints }\end{array}$ & -..171- -.112 & .074 .058 & .135 .124 & .079.017 & .012-016 & .010 .070 & .017.055 & $-.143-.120$ & -199 -154 & -108 \\
\hline Suicide & $-.190-.093$ & -.027 .002 & -.009 .001 & $.047-.038$ & -.039.017 & -.143 .039 & .014 .065 & -..157 - -052 & $.002-.140$ & $-.009-.123$ \\
\hline Psychosis & $.120-.015$ & .100 .077 & .169 .080 & .029 .068 & $.083-.013$ & .009 .085 & .055.057 & $-.134-.024$ & $.041-.048$ & $-.006-.068$ \\
\hline Sleep Problems & $-.147-.037$ & .026 .033 & .105. 141 & $.108-012$ & $.097-.035$ & .067 .052 & .125 .078 & -.237-.066 & - & $-.042-.023$ \\
\hline Memory & $-.030-.035$ & .055 .005 & .044 .039 & $.033-.027$ & $.031-.072$ & -.022 .046 & $.026-.025$ & - & $.024-.065$ & -.058- -.026 \\
\hline $\begin{array}{l}\text { Repetitive } \\
\text { Behaviors }\end{array}$ & .014 .029 & $.031-.014$ & .087 .095 & $.014-.028$ & $.073-019$ & -.034 .051 & -.034 .034 & $-.185-.074$ & .012- -099 & $-.081-.044$ \\
\hline Dissociation & $-.004-.023$ & .062 .035 & .079 .090 & $.058-.058$ & 082.019 & -.090 .080 & .000 .120 & $-.075-.049$ & $-.143-.154$ & -..177 -.091 \\
\hline $\begin{array}{l}\text { Personality } \\
\text { Problems }\end{array}$ & $-.125-.023$ & .044 .070 & .070 .190 & .104 .027 & .065 .025 & -.008 .115 & .042 .107 & $-.151-.095$ & $-.078-159$ & $-.168-.101$ \\
\hline Substance Use & $.059-.071$ & $.084-.137$ & $.068-155$ & $-.032-.129$ & $-.005-.079$ & $-.045-.127$ & $-129-.145$ & .026 .072 & .093.086 & .068.049 \\
\hline AUDIT & $-.027-.092$ & . $011-156$ & $.071-.121$ & .016- .164 & -.151 -.178 & $-.001-.229$ & -.123-.246 & -.033 .043 & . 189.052 & .290 .115 \\
\hline
\end{tabular}

Note: Numbers at top of the cells are from the Spring 2020 cohort and numbers on the bottom of the cells are from the Fall 2020 cohort; all correlations $>.20$ are bolded 
Table 5

Differences in well-being variables across pre-pandemic and pandemic semesters.

\begin{tabular}{|c|c|c|c|c|c|c|}
\hline & Semester & M & SD & $\mathrm{F}$ & $\mathrm{p}$ & $\begin{array}{l}\text { Partial } \\
\eta^{2}\end{array}$ \\
\hline \multirow[t]{4}{*}{ Depression } & Fall 2019 & 1.98 & 1.02 & 3.74 & .024 & .011 \\
\hline & Spring & 2.24 & 1.03 & & & \\
\hline & 2020 & & & & & \\
\hline & Fall 2020 & 1.95 & 1.14 & & & \\
\hline \multirow[t]{4}{*}{ Anger } & Fall 2019 & 1.69 & 0.91 & 8.02 & $<.001$ & .023 \\
\hline & Spring & 1.99 & 1.02 & & & \\
\hline & 2020 & & & & & \\
\hline & Fall 2020 & 1.56 & 1.16 & & & \\
\hline \multirow[t]{4}{*}{ Mania } & Fall 2019 & 1.74 & 0.88 & 8.77 & $<.001$ & .025 \\
\hline & Spring & 1.94 & 1.02 & & & \\
\hline & 2020 & & & & & \\
\hline & Fall 2020 & 1.50 & 1.24 & & & \\
\hline \multirow[t]{4}{*}{ Anxiety } & Fall 2019 & 2.22 & 1.06 & 0.72 & .488 & .002 \\
\hline & Spring & 2.32 & 1.10 & & & \\
\hline & 2020 & & & & & \\
\hline & Fall 2020 & 2.17 & 1.34 & & & \\
\hline \multirow{4}{*}{$\begin{array}{l}\text { Somatic } \\
\text { Complaints }\end{array}$} & Fall 2019 & 1.70 & 0.98 & 7.92 & $<.001$ & .023 \\
\hline & Spring & 1.66 & 0.92 & & & \\
\hline & 2020 & & & & & \\
\hline & Fall 2020 & 1.34 & 1.30 & & & \\
\hline \multirow[t]{4}{*}{ Suicide } & Fall 2019 & 0.29 & 0.81 & 0.30 & .745 & .004 \\
\hline & Spring & 0.33 & 0.93 & & & \\
\hline & 2020 & & & & & \\
\hline & Fall 2020 & 0.27 & 0.74 & & & \\
\hline \multirow[t]{4}{*}{ Psychosis } & Fall 2019 & 0.25 & 0.76 & 0.56 & .572 & .002 \\
\hline & Spring & 0.25 & 0.71 & & & \\
\hline & 2020 & & & & & \\
\hline & Fall 2020 & 0.32 & 0.89 & & & \\
\hline \multirow[t]{4}{*}{ Sleep Problems } & Fall 2019 & 1.48 & 1.27 & 0.79 & .454 & .002 \\
\hline & Spring & 1.64 & 1.41 & & & \\
\hline & 2020 & & & & & \\
\hline & Fall 2020 & 1.50 & 1.31 & & & \\
\hline \multirow[t]{4}{*}{ Memory } & Fall 2019 & 0.78 & 1.12 & 0.35 & .702 & .001 \\
\hline & Spring & 0.86 & 1.30 & & & \\
\hline & 2020 & & & & & \\
\hline & Fall 2020 & 0.77 & 1.07 & & & \\
\hline \multirow{4}{*}{$\begin{array}{l}\text { Repetitive } \\
\text { Behaviors }\end{array}$} & Fall 2019 & 0.89 & 1.18 & 9.98 & $<.001$ & .029 \\
\hline & Spring & 0.90 & 1.25 & & & \\
\hline & 2020 & & & & & \\
\hline & Fall 2020 & 1.42 & 1.84 & & & \\
\hline \multirow[t]{4}{*}{ Dissociation } & Fall 2019 & 0.93 & 1.33 & 0.06 & .942 & .000 \\
\hline & Spring & 0.97 & 1.31 & & & \\
\hline & 2020 & & & & & \\
\hline & Fall 2020 & 0.96 & 1.18 & & & \\
\hline \multirow[t]{4}{*}{ Personality } & Fall 2019 & 1.48 & 1.41 & 17.70 & $<.001$ & .050 \\
\hline & Spring & 1.51 & 1.45 & & & \\
\hline & 2020 & & & & & \\
\hline & Fall 2020 & 2.34 & 2.28 & & & \\
\hline \multirow[t]{4}{*}{ Substance Use } & Fall 2019 & 0.47 & 0.94 & 0.31 & .732 & .001 \\
\hline & Spring & 0.45 & 0.88 & & & \\
\hline & 2020 & & & & & \\
\hline & Fall 2020 & 0.52 & 1.24 & & & \\
\hline \multirow[t]{4}{*}{ Perceived Stress } & Fall 2019 & 19.60 & 6.78 & 2.50 & .083 & .008 \\
\hline & Spring & 21.21 & 7.22 & & & \\
\hline & 2020 & & & & & \\
\hline & Fall 2020 & 19.99 & 6.63 & & & \\
\hline \multirow{4}{*}{$\begin{array}{l}\text { Alcohol use } \\
\text { (AUDIT) }\end{array}$} & Fall 2019 & 3.29 & 3.47 & 3.44 & .033 & .010 \\
\hline & Spring & 4.14 & 4.64 & & & \\
\hline & 2020 & & & & & \\
\hline & Fall 2020 & 3.11 & 3.91 & & & \\
\hline
\end{tabular}

$(\mathrm{F}(1,621)=4.27, \mathrm{p}=.039)$, sleep problems $(\mathrm{F}(1,621)=7.05, \mathrm{p}=$ $.008)$, perceived stress $(\mathrm{F}(1,621)=2.49, \mathrm{p}=.004)$ and alcohol misuse $(\mathrm{F}(1,621)=29.09, \mathrm{p}=.046)$ such that White students reported more symptoms of anger, anxiety, sleep problems, perceived stress, and alcohol use than did African American students. African American students reported more symptoms of mania and psychosis than did White students. In addition, there was an interaction between semester and race on anger symptoms $(\mathrm{F}(2,621)=4.17, \mathrm{p}=.016)$ such that White students reported higher levels of anger during the initial weeks of the pandemic but were similar to African American students at other timepoints.

\section{Discussion}

This study compared college students in the southeastern United States tested prior to the COVID-19 pandemic with similar samples tested during the pandemic on measures of psychological symptoms, perceived stress, and alcohol use. The results provide insight into how the early months of the COVID-19 pandemic and associated disruption affected the mental health and well-being of young adults, and how things had largely returned to typical levels by fall 2020 despite continued physical distancing, restrictions on travel and in-person gatherings, etc. Although young adults are generally not as prone to experiencing severe symptoms of COVID-19 as are older adults, this study demonstrates how they were nonetheless psychologically impacted by the pandemic. Specifically, participants who completed the study during the initial weeks of the COVID-19 pandemic in the U.S. reported higher levels of mood disorder symptoms, perceived stress, and alcohol misuse as compared to those who completed the study prior to the pandemic. Further, there were racial differences in scores across the semesters on several variables. Beyond these semester-based differences, data collected on associations between students' perceptions of COVID19 and their well-being during the pandemic demonstrates how individual differences in pandemic-related worries may be a mechanism through which the pandemic has a negative impact on well-being, at least in the early weeks.

The results of this study are generally consistent with hypotheses and previous research on the impact of pandemics on psychological wellbeing. Specifically, the hypothesis regarding the association between concerns about COVID-19 and well-being was supported. Participants who indicated greater concern about them or a loved one contracting COVID-19 and those who reported that others in their life were not being careful enough about avoiding infection reported higher levels of depression, anger, anxiety, and perceived stress in spring 2020. This finding is consistent with research on the general population in China during the COVID-19 outbreak showing that greater concern about oneself or a loved one contracting COVID-19 is associated with higher self-reported stress (C. Wang et al., 2020a, 2020b) and provides more information about the impact of these concerns on specific domains on psychological symptoms. This result is important given the amount of concern about COVID-19 that is present in the general population in recent surveys (American Psychiatric Association, 2020). Individuals who experience higher levels of worry about the dangers of COVID-19 for themselves or loved ones might benefit from targeted interventions. However, it is also important to note that students tested in fall 2020 showed few associations between COVID-related concerns and mental health symptoms.

Additionally, results examining semester effects supported the hypothesis that participants during the pandemic would report higher levels of depression, perceived stress, and alcohol misuse. However, predicted higher rates of anxiety during the pandemic were not found and the results for symptom increases that were detected were generally at the "mild" level and present during the initial weeks of the pandemic but not in fall 2020. The increases in depressive symptoms and perceived stress during the pandemic semester are consistent with research on the psychological effects experienced by infected patients during previous epidemics (Batawi et al., 2019; Lee et al., 2018; Mak et al., 2009; Mohammed et al., 2015) and the increases in perceived stress and anger are also congruent with research on the effects of being quarantined (Brooks et al., 2020). The lack of a difference in anxiety scores between the two samples, despite a difference in conceptually-related perceived stress, might mean that college-aged individuals, unlike other age groups, do not experience an increase in anxiety during a pandemic. Alternatively, it is possible that the CCSM anxiety items, which describe 
Table 6

Differences in well-being by semester and race in White and African American students

\begin{tabular}{|c|c|c|c|c|c|c|c|}
\hline & & & & & Signif & e full model & \\
\hline & Semester & Race & M & SD & $\mathrm{F}$ & $\mathrm{p}$ & Partial $\eta^{2}$ \\
\hline Depression & Fall 2019 & African American & 2.03 & 1.03 & 2.42 & .035 & .019 \\
\hline & & White & 1.96 & 1.01 & & & \\
\hline & Spring 2020 & African American & 2.09 & 1.02 & & & \\
\hline & & White & 2.41 & 1.02 & & & \\
\hline & Fall 2020 & African American & 2.01 & 1.28 & & & \\
\hline & & White & 1.88 & 1.06 & & & \\
\hline Anger & Fall 2019 & African American & 1.70 & 1.12 & 5.58 & $<.001$ & .043 \\
\hline & & White & 1.71 & 1.27 & & & \\
\hline & Spring 2020 & African American & 1.67 & 1.24 & & & \\
\hline & & White & 2.31 & 1.45 & & & \\
\hline & Fall 2020 & African American & 1.49 & 1.17 & & & \\
\hline & & White & 1.59 & 1.14 & & & \\
\hline Mania & Fall 2019 & African American & 1.77 & 0.88 & 4.90 & $<.001$ & .038 \\
\hline & & White & 1.70 & 0.88 & & & \\
\hline & Spring 2020 & African American & 2.10 & 1.08 & & & \\
\hline & & White & 1.78 & 1.00 & & & \\
\hline & Fall 2020 & African American & 1.66 & 1.28 & & & \\
\hline & & White & 1.40 & 1.22 & & & \\
\hline Anxiety & Fall 2019 & African American & 2.23 & 1.08 & 2.87 & .014 & .023 \\
\hline & & White & 2.26 & 1.04 & & & \\
\hline & Spring 2020 & African American & 2.13 & 1.06 & & & \\
\hline & & White & 2.55 & 1.05 & & & \\
\hline & Fall 2020 & African American & 1.85 & 1.37 & & & \\
\hline & & White & 2.27 & 1.29 & & & \\
\hline Somatic Complaints & Fall 2019 & African American & 1.77 & 1.01 & 3.75 & .002 & .029 \\
\hline & & White & 1.70 & 0.97 & & & \\
\hline & Spring 2020 & African American & 1.60 & 0.86 & & & \\
\hline & & White & 1.73 & 1.00 & & & \\
\hline & Fall 2020 & African American & 1.27 & 1.31 & & & \\
\hline & & White & 1.35 & 1.29 & & & \\
\hline Suicide & Fall 2019 & African American & 0.39 & 0.86 & 1.08 & .372 & .009 \\
\hline & & White & 0.27 & 0.83 & & & \\
\hline & Spring 2020 & African American & 0.20 & 0.73 & & & \\
\hline & & White & 0.42 & 1.05 & & & \\
\hline & Fall 2020 & African American & 0.22 & 0.68 & & & \\
\hline & & White & 0.24 & 0.66 & & & \\
\hline Psychosis & Fall 2019 & African American & 0.45 & 0.98 & 2.21 & .052 & .017 \\
\hline & & White & 0.17 & 0.65 & & & \\
\hline & Spring 2020 & African American & 0.27 & 0.82 & & & \\
\hline & & White & 0.20 & 0.55 & & & \\
\hline & Fall 2020 & African American & 0.45 & 1.17 & & & \\
\hline & & White & 0.23 & 0.70 & & & \\
\hline Sleep Problems & Fall 2019 & African American & 1.42 & 1.31 & 2.10 & .063 & .017 \\
\hline & & White & 1.52 & 1.23 & & & \\
\hline & Spring 2020 & African American & 1.44 & 1.43 & & & \\
\hline & & White & 1.97 & 1.38 & & & \\
\hline & Fall 2020 & African American & 1.33 & 1.30 & & & \\
\hline & & White & 1.60 & 1.30 & & & \\
\hline Memory & Fall 2019 & African American & 0.80 & 1.06 & 1.07 & .376 & .009 \\
\hline & & White & 0.77 & 1.16 & & & \\
\hline & Spring 2020 & African American & 0.81 & 1.17 & & & \\
\hline & & White & 0.92 & 1.47 & & & \\
\hline & Fall 2020 & African American & 0.54 & 0.90 & & & \\
\hline & & White & 0.85 & 1.12 & & & \\
\hline Repetitive Behaviors & Fall 2019 & African American & 1.05 & 1.25 & 3.62 & .003 & .028 \\
\hline & & White & 0.81 & 1.14 & & & \\
\hline & Spring 2020 & African American & 0.81 & 1.28 & & & \\
\hline & & White & 1.06 & 1.28 & & & \\
\hline & Fall 2020 & African American & 1.24 & 1.72 & & & \\
\hline & & White & 1.44 & 1.87 & & & \\
\hline Dissociation & Fall 2019 & African American & 1.15 & 1.51 & 0.89 & .488 & .007 \\
\hline & & White & 0.86 & 1.25 & & & \\
\hline & Spring 2020 & African American & 1.13 & 1.41 & & & \\
\hline & & White & 0.83 & 1.27 & & & \\
\hline & Fall 2020 & African American & 0.94 & 1.18 & & & \\
\hline & & White & 0.96 & 1.15 & & & \\
\hline Personality & Fall 2019 & African American & 1.45 & 1.42 & 5.31 & $<.001$ & .041 \\
\hline & & White & 1.50 & 1.41 & & & \\
\hline & Spring 2020 & African American & 1.56 & 1.47 & & & \\
\hline & & White & 1.59 & 1.48 & & & \\
\hline & Fall 2020 & African American & 2.39 & 2.50 & & & \\
\hline & & White & 2.20 & 2.09 & & & \\
\hline Substance Use & Fall 2019 & African American & 0.34 & 0.86 & 2.56 & .026 & .020 \\
\hline
\end{tabular}




\begin{tabular}{|c|c|c|c|c|c|c|c|}
\hline & \multirow[b]{2}{*}{ Semester } & \multirow[b]{2}{*}{ Race } & \multirow[b]{2}{*}{ M } & \multirow[b]{2}{*}{ SD } & \multicolumn{2}{|c|}{ Significance of the full model } & \multirow[b]{2}{*}{ Partial $\eta^{2}$} \\
\hline & & & & & $\mathrm{F}$ & $\mathrm{p}$ & \\
\hline & & White & 0.54 & 0.99 & & & \\
\hline & Spring 2020 & African American & 0.36 & 0.78 & & & \\
\hline & & White & 0.55 & 0.96 & & & \\
\hline & Fall 2020 & African American & 0.24 & 0.69 & & & \\
\hline & & White & 0.67 & 1.43 & & & \\
\hline \multirow[t]{6}{*}{ Perceived Stress } & Fall 2019 & African American & 19.05 & 6.94 & 1.88 & .095 & .016 \\
\hline & & White & 20.23 & 6.55 & & & \\
\hline & Spring 2020 & African American & 20.81 & 6.83 & & & \\
\hline & & White & 22.40 & 7.13 & & & \\
\hline & Fall 2020 & African American & 19.89 & 7.02 & & & \\
\hline & & White & 19.95 & 6.57 & & & \\
\hline \multirow[t]{6}{*}{ AUDIT } & Fall 2019 & African American & 2.06 & 2.78 & 7.26 & $<.001$ & .057 \\
\hline & & White & 3.91 & 3.66 & & & \\
\hline & Spring 2020 & African American & 3.22 & 4.38 & & & \\
\hline & & White & 5.21 & 4.74 & & & \\
\hline & Fall 2020 & African American & 1.99 & 2.40 & & & \\
\hline & & White & 3.72 & 4.29 & & & \\
\hline
\end{tabular}

Note: = African American Fall 2019 N =64, White Fall 2019 N = 140, African American Spring 2020 N =64, White Spring 2020 N = 61

worry, panic, and avoidance, do not capture the psychological impact of the pandemic on young adults in the area of anxiety. In combination with the results indicating that concerns about COVID-19 were not associated with symptoms in fall 2020, it may be worth considering that any symptoms present in the initial weeks of the pandemic in the U.S. had resolved by fall 2020 without intervention. This would be consistent with theories about general life satisfaction, which suggest that people have a set level of satisfaction that can be briefly changed by life events but will eventually recalibrate (Fujita and Diener, 2005). Additionally, because this is not a longitudinal study it should also be mentioned that the participants tested in spring 2020 and fall 2020 are not the same people, and that individuals who coped more poorly with COVID-19-related stress and disruption may have no longer been enrolled in college in fall 2020.

Most of the research to date on the psychological effects of pandemics has not considered how pandemics impact substance use behaviors, despite the associations between alcohol misuse and anxiety (Smith \& Randall, 2012), depression (McHugh \& Weiss, 2019), and stress (Keyes et al., 2012), all of which appear to increase during a pandemic. This study therefore makes a novel contribution to the literature by demonstrating that across three samples of predominately female college students, those assessed during the initial weeks of the COVID-19 pandemic in the U.S. reported drinking alcohol at higher levels that were, on average, in the risky range for women (Johnson et al., 2013). This is consistent with other studies of general population increases in alcohol use during the pandemic (e.g., Avery et al., 2020; Pollard et al., 2020; Tran et al., 2020) but provides insight about the specific nature and timing of this phenomenon among college students. Increased alcohol use in young adult females is of particular concern given the increased rates of comorbid AUD, anxiety and depressive disorders among women as compared to men (Kessler 2003; Kessler et al., 1997; Khan et al., 2013). Further, among individuals suffering from dual diagnoses (e.g., AUD and depression) symptoms and prognosis can be worse than for individuals with only one disorder (Conner et al., 2014).

Exploratory analyses on racial differences in the impact of the pandemic revealed that White students reported more anger, mania, anxiety, psychosis, sleep problems, perceived stress, and alcohol misuse than did African American students in both the pre-pandemic and the pandemic semesters. Additionally, White students reported higher levels of anger specifically during the early weeks of the pandemic whereas African American students did not show this effect. The lower levels of symptoms reported by African American students is somewhat unexpected given studies of other national disasters which suggest that African Americans may be more vulnerable to experiencing psychological symptoms after such events as compared to White individuals (Elliott and Pais, 2006; Perilla et al., 2002). One difference to note is that these studies were conducted after the disasters had already occurred whereas the current study was conducted during the COVID-19 national emergency, albeit at two different time points during its course. Additionally, African American students could be reporting fewer psychological symptoms due having more resilience to new stressors. African American students are more likely to have experienced other life stressors (e. g., higher rate of poverty, higher mortality rates from disease, fewer employment opportunities, racial discrimination) as compared to White students (Assari and Lankarani, 2016; Brown, 2008, 2011) which could build resilience to new stressors associated with the COVID-19 outbreak. Additionally, racial socialization and supportive social networks have been associated with resiliency among African American college students (Brown, 2008). However, it should also be noted that this finding could be due to African American students' reluctance to share sensitive information with researchers (Assari and Lankarani, 2016) and greater stigmatization of mental illness among African Americans (Anglin et al., 2006). It is therefore possible that the data presented here underestimate the psychological impact of the COVID-19 pandemic on African American college students and more research on this is warranted.

The results of this study, in combination with related studies cited here, suggest that members of the general public are at risk for negative impacts of the COVID-19 pandemic on their well-being but that this risk may have been more acute in the early weeks of the pandemic than it is some six months in to the "new normal." During future pandemics or similar situations it may be advisable for individuals to adhere to the following recommendations to decrease the likelihood of significant negative psychological impairment: avoid excessive exposure to COVID19 media coverage but ensure you are well-informed via reliable media sources; enhance and/or maintain physical health; seek out safe (e.g., virtual) ways to obtain social support; maintain daily routines; and engage in relaxation techniques to reduce stress. Research on other kinds of life stressors and trauma suggests that coping strategies can mitigate their impact (Benight \& Harper, 2002; McPherson et al., 2003; Vosvick et al., 2003), so learning about and using healthy coping skills is also likely to be beneficial. Further, given the findings suggesting increased psychological symptoms among individuals who were worried about how whether loved ones were engaging in sufficient safety behaviors, it would be helpful to promote the seriousness of COVID-19 and the importance of safety precautions in both personal relationships and society as a whole. Lastly, educating the public about the fact that any increases in mental health symptoms or perceived stress during the pandemic are likely short-lived and will resolve on their own may help assuage concerns and promote more optimism.

Given the results of this study of college students, mental health professionals and college administrators may consider several 
recommendations. First, most students generally cope well with the pandemic and show non-clinical levels of symptoms. However, there are average increases in several indicators of psychological maladjustment as well as alcohol use among college students that is most acute in the initial weeks following the institution of public health guidelines and societal changes aimed at reducing the spread of COVID-19. These effects might impact students' academic success and longer-term wellbeing, and students may benefit from education and resources targeted toward these outcomes. Professionals should also keep in mind the trajectory and progression of the COVID-19 pandemic, which is different from many other types of trauma in that many disasters are one-day events. Although the third wave of data collected for this study show promising indicators that students are managing their mental health and behavior better now than they were in the first weeks of the pandemic, the ultimate mental health effects of this pandemic cannot be known at the time of this study. Both short- and long-term mental health services may be needed for some individuals. One intervention that may be useful to deploy during the initial stages of a pandemic or similar event is psychological first aid, which focuses on mitigating acute distress, providing support, and assessing the need for continued mental healthcare (Everly \& Flynn, 2006).

Second, college mental health professionals should consider that students could lack social support or may experience stigma related to seeking mental healthcare once they are away from campus, thereby hindering their ability to reach out for help if they do experience clinical symptoms during an event like a pandemic. Clinicians should find ways to make mental healthcare accessible, such as through telehealth services which have been found effective in treating anxiety and depressive symptoms (Brenes et al., 2015). Further, as was done during the COVID-19 pandemic in the U.S., local jurisdictions should consider relaxing interjurisdictional practice guidelines for college students so that college counseling centers can continue to serve them if they return to a family home out of state. Third, college mental health providers should also consider that alcohol use and associated problems are typically elevated among college students (O'Malley \& Johnston, 2002). As indicated by the AUDIT scores in the present study, alcohol use increases to the point of risky or even more elevated levels during the pandemic for some college students. This increased use may be a maladaptive coping pattern that can interfere with social, academic, emotional, etc. functioning even if it is only a short-term impact of the pandemic (Park \& Grant, 2005; Perkins, 2002; White \& Hingson, 2013). As such, universities should provide students with resources related specifically to preventing alcohol misuse during stressors like the COVID-19 pandemic.

This study evaluated several indicators of well-being among college students in a unique and important time period in public health. The sample was fairly large and more racially diverse than some research efforts. The study also included a specific examination of racial differences, contributing to research on racial disparities and representation of different racial groups in psychological research. Further, the samples were examined within an approximately 15-month period, at the same university, and with the same self-report measures. However, it is not without limitations. The study's sample was composed of college students and was primarily female. As such, results may not generalize to other populations. Further, the study relied on self-report measures that were limited in detail and may have been subject to reporting biases. Results in this non-clinical sample also demonstrated only modest increases in symptoms of various problems during the pandemic and many of these symptoms were not expressed at clinically significant levels. However, considering the age of the sample and the general negative impact of even modest increases in mood disorder symptoms, stress, and alcohol use on overall well-being, these results nonetheless illustrate important information about the impact of the COVID-19 pandemic on college students' adjustment. Future research should endeavor to further explore these effects as the pandemic continues.

\section{Declaration of Competing Interest}

None

\section{Acknowledgements}

None

\section{Supplementary materials}

Supplementary material associated with this article can be found, in the online version, at doi:10.1016/j.psychres.2021.113706.

\section{References}

Allenby, B., Fink, J., 2005. Toward inherently secure and resilient societies. Science (80). https://doi.org/10.1126/science.1111534.

Anglin, D.M., Link, B.G., Phelan, J.C., 2006. Racial differences in stigmatizing attitudes toward people with mental illness. Psychiatric Services 57 (6), 857-862.

Assari, S., Lankarani, M.M., 2016. Association between stressful life events and depression; intersection of race and gender. Journal of Racial and Ethnic Health Disparities 3 (2), 349-356.

Auerbach, R.P., Alonso, J., Axinn, W.G., Cuijpers, P., Ebert, D.D., Green, J.G., Hwang, I., Kessler, R.C., Liu, H., Mortier, P., Nock, M.K., Pinder-Amaker, S., Sampson, N.A., Aguilar-Gaxiola, S., Al-Hamzawi, A., Andrade, L.H., Benjet, C., Caldas-De-

Almeida, J.M., Demyttenaere, K., Florescu, S., De Girolamo, G., Gureje, O., Haro, J. M., Karam, E.G., Kiejna, A., Kovess-Masfety, V., Lee, S., McGrath, J.J., O'Neill, S., Pennell, B.E., Scott, K., Ten Have, M., Torres, Y., Zaslavsky, A.M., Zarkov, Z., Bruffaerts, R., 2016. Mental disorders among college students in the World Health Organization World Mental Health Surveys. Psychol. Med. 46, 2955-2970. https:// doi.org/10.1017/S0033291716001665.

Avery, A.R., Tsang, S., Seto, E.Y.W., Duncan, G.E., 2020. Stress, Anxiety, and Change in Alcohol Use During the COVID-19 Pandemic: Findings Among Adult Twin Pairs. Front. Psychiatry 11. https://doi.org/10.3389/fpsyt.2020.571084.

Batawi, S., Tarazan, N., Al-Raddadi, R., Al Qasim, E., Sindi, A., Al Johni, S., AlHameed, F.M., Arabi, Y.M., Uyeki, T.M., Alraddadi, B.M., 2019. Quality of life reported by survivors after hospitalization for Middle East respiratory syndrome (MERS). Health Qual. Life Outcomes 17. https://doi.org/10.1186/s12955-0191165-2.

Baum, A., Posluszny, D.M., 1999. HEALTH PSYCHOLOGY: Mapping Biobehavioral Contributions to Health and Illness. Annu. Rev. Psychol. 50, 137-163. https://doi. org/10.1146/annurev.psych.50.1.137.

Benight, C.C., Harper, M.L., 2002. Coping self-efficacy perceptions as a mediator between acute stress response and long-term distress following natural disasters. Journal of Traumatic Stress: Official Publication of The International Society for Traumatic Stress Studies 15 (3), 177-186. https://doi.org/10.1023/a: 1015295025950.

Brenes, G.A., Danhauer, S.C., Lyles, M.F., Hogan, P.E., Miller, M.E., 2015. Telephonedelivered cognitive behavioral therapy and telephone-delivered nondirective supportive therapy for rural older adults with generalized anxiety disorder: A randomized clinical trial. JAMA Psychiatry 72 (10), 1012-1020. https://doi.org/ 10.1001/jamapsychiatry.2015.1154.

Brooks, S.K., Webster, R.K., Smith, L.E., Woodland, L., Wessely, S., Greenberg, N., Rubin, G.J., 2020. The psychological impact of quarantine and how to reduce it: rapid review of the evidence. Lancet 395, 912-920. https://doi.org/10.1016/S01406736(20)30460-8.

Brown, D.L., 2008. African American resiliency: Examining racial socialization and social support as protective factors. Journal of Black Psychology 34 (1), 32-48. https://doi. org/10.1177/0095798407310538.

Brown, D.L., 2011. Racial discrimination and resilience in African American young adults: Examining racial socialization as a moderator. Journal of Black Psychology 37 (3), 259-285. https://doi.org/10.1177/0095798410390689.

Cao, W., Fang, Z., Hou, G., Han, M., Xu, X., Dong, J., Zheng, J., 2020. The psychological impact of the COVID-19 epidemic on college students in China. Psychiatry Res 287, 112934. https://doi.org/10.1016/j.psychres.2020.112934.

Centers for Disease Control and Prevention, 2020. Coronavirus disease 2019 (COVID-19) [WWW Document]. URL https://www.cdc.gov/coronavirus/2019-ncov/cases-updat es/cases-in-us.html (accessed 3.17.20).

Chi, X., Becker, B., Yu, Q., Willeit, P., Jiao, C., Huang, L., Hossain, M.M., Grabovac, I., Yeung, A., Lin, J., Veronese, N., Wang, J., Zhou, X., Doig, S.R., Liu, X., Carvalho, A. F., Yang, L., Xiao, T., Zou, L., Fusar-Poli, P., Solmi, M., 2020. Prevalence and Psychosocial Correlates of Mental Health Outcomes Among Chinese College Students During the Coronavirus Disease (COVID-19) Pandemic. Front. Psychiatry 11 (1). https://doi.org/10.3389/fpsyt.2020.00803.

Cohen, S., Kamarck, T., Mermelstein, R., 1983. A global measure of perceived stress. Journal of Health and Social Behavior 24 (4), 386-396, 10.2307/2136404.

Conner, K.R., Gamble, S.A., Bagge, C.L., He, H., Swogger, M.T., Watts, A., Houston, R.J., 2014. Substance-induced depression and independent depression in proximal risk for suicidal behavior. Journal of studies on alcohol and drugs 75 (4), 567-572.

Copeland, W.E., McGinnis, E., Bai, Y., Adams, Z., Nardone, H., Devadanam, V., Rettew, J., Hudziak, J.J., 2020. Impact of COVID on College Student Mental Health 
and Wellness. J. Am. Acad. Child Adolesc. Psychiatry 60, 134-141. https://doi.org/ 10.1016/j.jaac.2020.08.466 e2.

Elliott, J.R., Pais, J., 2006. Race, class, and Hurricane Katrina: Social differences in human responses to disaster. Social Science Research 35 (2), 295-321. https://doi. org /10.1016/j.ssresearch.2006.02.003.

Everly Jr, G.S., Flynn, B.W., 2006. Principles and practical procedures for acute psychological first aid training for personnel without mental health experience. International Journal of Emergency Mental Health 8 (2), 93-100.

Fujita, F., Diener, E., 2005. Life satisfaction set point: Stability and change. J. Pers. Soc. Psychol. https://doi.org/10.1037/0022-3514.88.1.158.

Gao, J., Zheng, P., Jia, Y., Chen, H., Mao, Y., Chen, S., Wang, Y., Fu, H., Dai, J., 2020. Mental health problems and social media exposure during COVID-19 outbreak. PLoS One 15. https://doi.org/10.1371/journal.pone.0231924.

Grant, B.F., Goldstein, R.B., Saha, T.D., Patricia Chou, S., Jung, J., Zhang, H., Pickering, R.P., June Ruan, W., Smith, S.M., Huang, B., Hasin, D.S., 2015 Epidemiology of DSM-5 alcohol use disorder results from the national epidemiologic survey on alcohol and related conditions III. JAMA Psychiatry 72, 757-766. https:// doi.org/10.1001/jamapsychiatry.2015.0584.

Huang, Y., Zhao, N., 2020. Generalized anxiety disorder, depressive symptoms and sleep quality during COVID-19 outbreak in China: a web-based cross-sectional survey. Psychiatry Res 288. https://doi.org/10.1016/j.psychres.2020.112954.

Husky, M.M., Kovess-Masfety, V., Swendsen, J.D., 2020. Stress and anxiety among university students in France during Covid-19 mandatory confinement. 10.1016/j. comppsych.2020.152191.

Johnson, J.A., Lee, A., Vinson, D., Seale, J.P., 2013. Use of AUDIT-Based Measures to Identify Unhealthy Alcohol Use and Alcohol Dependence in Primary Care: A Validation Study. Alcohol. Clin. Exp. Res. 37, E253-E259. https://doi.org/10.1111/ j.1530-0277.2012.01898.x.

Kecojevic, A., Basch, C.H., Sullivan, M., Davi, N.K., 2020. The impact of the COVID-19 epidemic on mental health of undergraduate students in New Jersey, cross-sectional study. PLoS One 15, e0239696. https://doi.org/10.1371/journal.pone.0239696.

Kessler, R.C., 2003. Epidemiology of women and depression. Journal of affective disorders 74 (1), 5-13.

Kessler, R.C., Crum, R.M., Warner, L.A., Nelson, C.B., Schulenberg, J., Anthony, J.C., 1997. Lifetime co-occurrence of DSM-III-R alcohol abuse and dependence with other psychiatric disorders in the National Comorbidity Survey. Archives of general psychiatry 54 (4), 313-321.

Kessler, R.C., Sonnega, A., Bromet, E., Hughes, M., Nelson, C.B., 1995. Posttraumatic Stress Disorder in the National Comorbidity Survey. Arch. Gen. Psychiatry 52, 1048-1060. https://doi.org/10.1001/archpsyc.1995.03950240066012.

Keyes, K.M., Hatzenbuehler, M.L., Grant, B.F., Hasin, D.S., 2012. Stress and alcohol: epidemiologic evidence. Alcohol research: current reviews.

Khan, S., Okuda, M., Hasin, D.S., Secades-Villa, R., Keyes, K., Lin, K.H., Blanco, C., 2013. Gender differences in lifetime alcohol dependence: results from the national epidemiologic survey on alcohol and related conditions. Alcoholism: Clinical and Experimental Research 37 (10), 1696-1705.

Lee, E.H., 2012. Review of the psychometric evidence of the Perceived Stress Scale. Asian Nursing Research 6 (4), 121-127. https://doi.org/10.1016/j.anr.2012.08.004.

Lee, S.M., Kang, W.S., Cho, A.R., Kim, T., Park, J.K., 2018. Psychological impact of the 2015 MERS outbreak on hospital workers and quarantined hemodialysis patients. Compr. Psychiatry 87, 123-127. https://doi.org/10.1016/j. compsych.2018.10.003.

Little, R.J.A, 1988. A test of missing completely at random for multivariate data with missing values. Journal of the American Statistical Association 83 (404), 1198-1202. https://doi.org/10.1080/01621459.1988.10478722.

Liu, N., Zhang, F., Wei, C., Jia, Y., Shang, Z., Sun, L., Wu, L., Sun, Z., Zhou, Y., Wang, Y., Liu, W., 2020. Prevalence and predictors of PTSS during COVID-19 outbreak in China hardest-hit areas: Gender differences matter. Psychiatry Res 287, 112921. https://doi.org/10.1016/j.psychres.2020.112921.

Mak, I.W.C., Chu, C.M., Pan, P.C., Yiu, M.G.C., Chan, V.L., 2009. Long-term psychiatric morbidities among SARS survivors. Gen. Hosp. Psychiatry 31, 318-326. https://doi. org/10.1016/j.genhosppsych.2009.03.001.

McHugh, R.K., Weiss, R.D, 2019. Alcohol use disorder and depressive disorders. Alcohol research: current reviews 40 (1).

McPherson, S., Hale, R., Richardson, P., Obholzer, A., 2003. Stress and coping in accident and emergency senior house officers. Emergency Medicine Journal 20 (3), 230-231. https://doi.org/10.1136/emj.20.3.230.

Mervosh, S., L, J.C., Gamio, L., Popovich, N., 2020. See how all 50 states are reopening. The New York Times. https://www.nytimes.com/interactive/2020/us/states-reope n-map-coronavirus.html.

Mohammed, A., Sheikh, T.L., Gidado, S., Poggensee, G., Nguku, P., Olayinka, A., Ohuabunwo, C., Waziri, N., Shuaib, F., Adeyemi, J., Uzoma, O., Ahmed, A., Doherty, F., Nyanti, S.B., Nzuki, C.K., Nasidi, A., Oyemakinde, A., Oguntimehin, O. Abdus-Salam, I.A., Obiako, R.O., 2015. An evaluation of psychological distress and social support of survivors and contacts of Ebola virus disease infection and their relatives in Lagos, Nigeria: A cross sectional study - 2014. BMC Public Health 15. https://doi.org/10.1186/s12889-015-2167-6.

Mościcki, E.K., Clarke, D.E., Kuramoto, S.J., Kraemer, H.C., Narrow, W.E., Kupfer, D.J., Regier, D.A., 2013. Testing DSM-5 in routine clinical practice settings: Feasibility and clinical utility. Psychiatr. Serv. 64, 952-960. https://doi.org/10.1176/appi. ps.201300098.

Narrow, W.E., Clarke, D.E., Kuramoto, S.J., Kraemer, H.C., Kupfer, D.J., Greiner, L., Regier, D.A., 2013. DSM-5 field trials in the United States and Canada, part III: Development and reliability testing of a cross-cutting symptom assessment for DSM5. American Journal of Psychiatry 170 (1), 71-82. https://doi.org/10.1176/appi. ajp.2012.12071000.
Overstreet, C., Berenz, E.C., Kendler, K.S., Dick, D.M., Amstadter, A.B., 2017. Predictors and mental health outcomes of potentially traumatic event exposure. Psychiatry Res 247, 296-304. https://doi.org/10.1016/j.psychres.2016.10.047.

O'Malley, P.M., Johnston, L.D., 2002. Epidemiology of alcohol and other drug use among American college students. Journal of Studies on Alcohol and Drugs 14 (1), 23-39. https://doi.org/10.15288/jsas.2002.s14.23.

Paltell, K.C., Smith, R.L., Kansky, J., Cox, C.M., Amstadter, A.B., Dick, D., 2020. The Spit for Science Working Group. In: Salvatore, J.E., Berenz, E.C. (Eds.), Posttraumatic stress disorder symptoms, relationship quality, and risky alcohol use among traumaexposed students. Addict. Behav., 102, 106216 https://doi.org/10.1016/j. addbeh.2019.106216.

Park, C.L., Grant, C., 2005. Determinants of positive and negative consequences of alcohol consumption in college students: Alcohol use, gender, and psychological characteristics. Addictive Behaviors 30 (4), 755-765. https://doi.org/10.1016/j. addbeh.2004.08.021.

Perilla, J.L., Norris, F.H., Lavizzo, E.A., 2002. Ethnicity, culture, and disaster response: Identifying and explaining ethnic differences in PTSD six months after Hurricane Andrew. Journal of Social and Clinical Psychology 21 (1), 20-45. https://doi.org/ 10.1521/jscp.21.1.20.22404.

Perkins, H.W., 2002. Surveying the damage: A review of research on consequences of alcohol misuse in college populations. Journal of Studies on Alcohol and Drugs 14 (1), 91-100. https://doi.org/10.15288/jsas.2002.s14.91.

Pollard, M.S., Tucker, J.S., Green, H.D., 2020. Changes in Adult Alcohol Use and Consequences During the COVID-19 Pandemic in the US. JAMA Netw. open 3, e2022942. https://doi.org/10.1001/jamanetworkopen.2020.22942.

Rubin, G.J., Potts, H.W.W., Michie, S., 2010. The impact of communications about swine flu (influenza A HINIv) on public responses to the outbreak: Results from 36 national telephone surveys in the UK. Health Technol. Assess. (Rockv). 14, 183-266. https:// doi.org/10.3310/hta14340-03.

Sim, K., Huak Chan, Y., Chong, P.N., Chua, H.C., Wen Soon, S., 2010. Psychosocial and coping responses within the community health care setting towards a national outbreak of an infectious disease. J. Psychosom. Res. 68, 195-202. https://doi.org/ 10.1016/j.jpsychores.2009.04.004.

Slutske, W.S., 2005. Alcohol use disorders among US college students and their noncollege-attending peers. Arch. Gen. Psychiatry 62, 321-327. https://doi.org/ 10.1001/archpsyc.62.3.321.

Slutske, W.S., Hunt-Carter, E.E., Nabors-Oberg, R.E., Sher, K.J., Bucholz, K.K., Madden, P.A.F., Anokhin, A., Heath, A.C., 2004. Do college students drink more than their non-college-attending peers? Evidence from a population-based longitudinal female twin study. J. Abnorm. Psychol. 113, 530-540. https://doi.org/10.1037/ 0021-843X.113.4.530.

Smith, J.P., Randall, C.L., 2012. Anxiety and alcohol use disorders: comorbidity and treatment considerations. Alcohol research: current reviews 34 (4), 414-431.

Sønderskov, K.M., Dinesen, P.T., Santini, Z.I., Østergaard, S.D., 2020. The depressive state of Denmark during the COVID-19 pandemic. Acta Neuropsychiatr 1-3. https:// doi.org/10.1017/neu.2020.15.

Tran, T.D., Hammarberg, K., Kirkman, M., Nguyen, H.T.M., Fisher, J., 2020. Alcohol use and mental health status during the first months of COVID-19 pandemic in Australia. J. Affect. Disord. 277, 810-813. https://doi.org/10.1016/j.jad.2020.09.012.

Van Bortel, T., Basnayake, A., Wurie, F., Jambai, M., Koroma, A.S., Muana, A.T., Hann, K., Eaton, J., Martin, S., Nellums, L.B., 2016. Psychosocial effects of an Ebola outbreak at individual, community and international levels. Bull. World Health Organ. 94, 210-214. https://doi.org/10.2471/BLT.15.158543.

Vosvick, M., Koopman, C., Gore-Felton, C., Thoresen, C., Krumboltz, J., Spiegel, D, 2003. Relationship of functional quality of life to strategies for coping with the stress of living with HIV/AIDS. Psychosomatics 44 (1), 51-58. https://doi.org/10.1176/appi. psy.44.1.51.

Wang, C., Pan, R., Wan, X., Tan, Y., Xu, L., Ho, C.S., Ho, R.C., 2020. Immediate psychological responses and associated factors during the initial stage of the 2019 coronavirus disease (COVID-19) epidemic among the general population in China. Int. J. Environ. Res. Public Health 17, 1729. https://doi.org/10.3390/ ijerph17051729.

Wang, C., Pan, R., Wan, X., Tan, Y., Xu, L., McIntyre, R.S., Choo, F.N., Tran, B., Ho, R., Sharma, V.K., Ho, C., 2020b. A longitudinal study on the mental health of general population during the COVID-19 epidemic in China. Brain. Behav. Immun. 0-1. https://doi.org/10.1016/j.bbi.2020.04.028.

Wang, X., Hegde, S., Son, C., Keller, B., Smith, A., Sasangohar, F., 2020. Investigating mental health of US college students during the COVID-19 pandemic: Cross-sectional survey study. J. Med. Internet Res. 22, e22817. https://doi.org/10.2196/22817.

White, A., Hingson, R., 2013. The burden of alcohol use: Excessive alcohol consumption and related consequences among college students. Alcohol Research: Current Reviews 35 (2), 201-218.

World Health Organization (2020). WHO Coronavirus Disease (COVID-19) Dashboard. https://covid19.who.int/table.

Wu, Z., McGoogan, J.M., 2020. Characteristics of and Important Lessons from the Coronavirus Disease 2019 (COVID-19) Outbreak in China: Summary of a Report of 72314 Cases from the Chinese Center for Disease Control and Prevention. JAMA - J. Am. Med. Assoc. https://doi.org/10.1001/jama.2020.2648.

Yu, H.Y.R., Ho, S.C., So, K.F.E., Lo, Y.L., 2005. Short communication: The psychological burden experienced by Hong Kong midlife women during the SARS epidemic. Stress Heal 21, 177-184. https://doi.org/10.1002/smi.1051.

Zhang, S.X., Wang, Y., Rauch, A., Wei, F., 2020. Unprecedented disruption of lives and work: Health, distress and life satisfaction of working adults in China one month into the COVID-19 outbreak. Psychiatry Res 288, 112958. https://doi.org/10.1016/j. psychres.2020.112958. 